\title{
CHILDREN FRIENDLY SCHOOLING TO FULFILL THE RIGHT TO EDUCATION
}

\author{
Bernadeta Resti Nurhayati \\ Fakultas Hukum dan Komunikasi \\ Universitas Katolik Soegijapranata Semarang \\ Email : resti@unika.ac.id
}

\begin{abstract}
Children are heir of a nation's future. Therefore, they ought to be comprehensively prepared both physically and psychologically in order to reach desired adulthood. Parents, trustee, and teachers together play important roles in this regard. To reach impeccable adulthood, fulfilling certain education extent has been serving obligatory purpose since long time ago. Generally, one child's education and well-being have been parent's responsibility. However, state guarantees every child access to proper education fulfillment, as it is written on UUD 1945 article 28 C, which ensures citizen development via basic physical needs fulfillment, including getting education and benefit from science, art, and cultural advantages in order to improve quality life. Yet in the middle of the process, sometimes they face obstacles in form of physical and psychological harassment. It can be, they find it delivered through playing groups, teaching teams, or surrounding adults. The complication has to be ignorance to education in general and school reluctant specifically. If the effect carries over they would eventually loss the opportunity of getting education rights served right. This paper aims to study access to education in general, harassment in school environment, and children-friendly school as an effort to fulfill education rights. According to the study the author concludes that education rights serve as one of human rights. Consequently, government guarantee its access to ensure education rights served right, including carrying out feasible actions and countermeasure to prevent and resolve problems in the society. The author would like to suggest children-friendly schooling in every city or regency in Indonesia.
\end{abstract}

Key words: children rights, education rights, children-friendly school

Introduction

Children are heir of a nation's future. Therefore, within their little body, finite knowledge, and lack of knowledge, they needs guidance, care, and accompaniment from parents or trustee in order to reach desired adulthood. Those needs basically are natural, nevertheless various countries arrange this particular matters.
Education fulfillment is essential rights to serve. Article 28C of Indonesia Constitution states:

(1) Every individuals are entitled to personal development through basic needs fulfillment, receiving education and benefiting from science and technology, art, as well as cultural advantages, in order to improve their quality living and social welfare. 
(2) Every individuals are entitled to promote theirselves in collective manner on contributing for society and their country.

It is written also in chapter XA about human rights, as well as education fulfillment as a part of it. Arranged as private law, education rights are not common law's domain to interfere in the first place.

However, since it is considered as human rights, government ought to stand for and provide education for the poor. This concept embodied on 12 years of primary education implementation. In fulfilling education rights, government organize free access for education from primary school to high school. Furthermore, they supply scholarship opportunities for accomplished students who aspire to get higher education but constrained financially.

Another problem is although getting education is getting more easier to get, oftentimes they might have been running into unsafe and uncomfortable experiences.

According to commissioner for education from Indonesian Children Protection Commision (KPAI), Retno Listiyani, cases which are reported as violence against education rights throughout January to April 2019 largely dominated by student bullying in the form of physical, psychological, and sexual harassment (https://news.detik.com). Those reports are stated below:

Tabel 1: Classification and count of violence against education rights cases throughout January to April 2019

\begin{tabular}{|c|l|c|}
\hline $\begin{array}{c}\mathrm{N} \\
\mathrm{o}\end{array}$ & \multicolumn{1}{|c|}{ Type } & Count \\
\hline 1. & $\begin{array}{l}\text { Mental harshness } \\
\text { and bullying }\end{array}$ & 12 \\
\hline 2. & Physical beatings & 3 \\
\hline 3. & Policy victims & 8 \\
\hline 4. & Sexual harrasment & 3 \\
\hline 5. & Physical violence & 8 \\
\hline 6. & $\begin{array}{l}\text { Bullying towards } \\
\text { teacher/instructor }\end{array}$ & 4 \\
\hline & & 37 \\
\hline
\end{tabular}

(Source: Indonesian Children Protection Commision (KPAI) data, 2019)

Based on education level, there are 37 cases reported on the same period as shown below:

Tabel 2: Frequency of violence against education rights for every level of education

\begin{tabular}{|l|l|c|c|}
\hline No & \multicolumn{1}{|c|}{ Level } & Count & $\begin{array}{c}\text { In Percentage } \\
(\%)\end{array}$ \\
\hline 1 & $\begin{array}{l}\text { Sekolah Dasar } \\
\text { Elementary School }\end{array}$ & 25 & 67,57 \\
\hline
\end{tabular}




\begin{tabular}{|l|l|c|c|}
\hline 2 & $\begin{array}{l}\text { Sekolah Menengah } \\
\text { Pertama } \\
\text { Junior High School }\end{array}$ & 5 & 13,51 \\
\hline 3 & $\begin{array}{l}\text { Sekolah Menengah Atas } \\
\text { Senior High School }\end{array}$ & 6 & 16,22 \\
\hline 4 & College Jumlah & 37 & 2,70 \\
\hline & \multicolumn{2}{|c|}{} \\
\hline
\end{tabular}

(Source: KPAI data 2019)

According to the data, it is quite notable that violence against education rights happen not only on elementary level but also on higher education levels. Children are evidently victim in most cases yet also appeared as the subject theirself. Hence, the author sees an particular approach is required to treat these case and fulfill education rights at once.

\section{Problem Statement}

Build upon prior analysis, the main problem to address in this paper is:

What approach need to be taken in order to get education rights assured?

\section{Analysis \\ Definition of Child}

There are various legal standings which regulate age ranges to define a child. Election Act states that 17 years old as the minimum age threshold for an individual to vote and contribute in the election. Act of Employment states that an individual is allowed to legally enter the labor market after reaching 14 years old. Commonly, anyone below 18 years old shall be considered as a child, including pre-nescency infants.

Children under 18 years old are parents' (or trustee) responsibility; including one to act on their behalf either within or outside legal situation. Children fully serve under parents and/or trustee protection and responsibility, including fulfillment of well-beingness and education. They need accompaniment from parents, trustee, teachers, and other companion to reach desired adulthood.

\section{Philosophical Base of Children Rights for Education}

At the early stage of positivism in Europe Continent, Government were occupied by codification of public and private law. The legislative house suggested solid recommendation to enforce alimony matters on private law. This is seen as it is shown in article 298 clause (2) of Burgerlijke Wetboek which stated: "Based on the clause, it is obligatory for every parents; both father and mother; to take care and educate their children. This obligation is not perish even under divorcement event. This leave us notable sense that the house had concern over children development as the regulation enforce preservation and education for children according parents property."

About whom to impose the cost of preservation and education, article 329a of Burgerlijke Wetboek stated: "Based on the article, the responsibility of preservation and education are commendable must although having constrained and adjusted to parents' earning and financial capability."

In the following era, when the constitutional state concept was on the glory days, the concept of welfare state 
started to flourish and blossom. Meanwhile, Indonesia as constitutional state was developed and recorded in the national constitution. It is written that:

Pursuant to which, in order to form a Government of the State of Indonesia that shall protect the whole people of Indonesia and the entire homeland of Indonesia, and in order to advance general prosperity, to develop the nation's intellectual life, and to contribute to the implementation of a world order based on freedom, lasting peace and social justice, Indonesia's National Independence shall be laid down in a Constitution of the State of Indonesia, which is to be established as the State of the Republic of Indonesia with sovereignty of the people and based on the belief in the One and Only God, on just and civilized humanity, on the unity of Indonesia and on democratic rule that is guided by the strength of wisdom resulting from deliberation / representation, so as to realize social justice for all the people of Indonesia.

The national objective of improving common welfare and educating national living are directly related with Pancasila as national principle, especially second and fifth principle. The passion to do so is literally quoted in the second principle which mentions equality, assurance of human rights with no exception to any ethnicity, offspring, religion, beliefs, gender, social status, color, and any other traits. It carries important significance about equality before the law, legal certainty, as well as acknowledgement towards human rights (http://jadipaham.com). It certainly has been strongly correlated with efforts to support education rights.
The tenth item of the fifth principle says: "Fond of perform activities to advocate prevalent and just advancement"

(http://jadipaham.com). This item contains value of good deeds which shall be practiced by all citizen; including make for educating nation living with education-related activities as well as striving for fairness. This term has broad meaning; including providing education support for the poor. This should have been government everlasting duty to fulfill.

Arguments on the fourth paragraph of national constitution 1945 are aligned with:

1) Article 1 Clause (3) of National Constitution 1945 which states: "Indonesia is a constitutional state." Hence, being one, all government-related tasks shall serve the prevailing law. The article becomes constitutional base that underlines a statement of Indonesia as constitutional state. Law stands as rule of play in the society and refers to Pancasila as national principles.

2) Article 28 point C clause (1) of National Constitution says: "Every individuals are entitled to personal development via basic physical needs fulfillment, including getting education and benefit from science, art, and cultural advantages in order to improve quality life

Reciprocally aligned with that statement, it is a responsibility for government to fulfil national wellbeingness, including educating national living by providing extensive education opportunity for every children.

\section{Children Right to Education}

Children right to education manifests solid implementation of the efforts of developing the nation's 
intellectual life. It is reflected on following regulations:

1) Act no. 23 of 2002 about Children Protection

It organizes a lot in terms of education, some of them are mentioned below:

Article 9 clause (1) set: "every child are entitled to education and teaching in order to achieve desired selfdevelopment and intellect according that serves their best interest and talent. In fact this article enforces absolute education access not only for ordinary but also children with special needs.

a) Article 48 set: "Government to provide compulsory 9 years of education for everyone"

b) Article 49 set: "State, government, relatives, and parents to provide wide opportunity to children to get education"

c) Article 54 set: "A child either within or outside schooling are bound to protect from any form of violence committed by teacher, schooling staffs, schoolmate, and also other educational institution.

In this article laid the most formidable legal standing for the idea of children-friendly schooling

2) Act that accommodate this particular national education system is a fundamental one when it comes to education in Indonesia. It regulates fair and wide opportunity for every individual to get quality education. This right must be served regardless of any given physical condition, health status, mental and psychological condition, and social standing. It also means, in case of children with special needs, quality education must still be delivered properly.
Right to education are basically attached to every individuals between 7 and 15 years old. This particular age range is the origin of 9 years of compulsory education program in Indonesia, even though in June of 2015 this program had been revised to 12 years in length of compulsory education, starting from elementary to senior high school. The word of "compulsory" leads to government solid implementation and assurance nowadays.

\section{Education and Nurturing Children}

According to Indonesian

Dictionary, words "didik" (to educate) and "mendidik" (to nurture) are classified as verb, that means "providing and bringing up exercise (teaching, guidance, direction) about morals and intelligence (https://www.kbbi.web.id).

While so, word "pendidikan" (education) is a noun. It can be interpreted as "attitude and behavior changing process of an individual or group in the course of maturity through teaching and training" or "process, deeds, way of educating (https://www.kbbi.web.id).

Education is mainly parents' duty to fulfill. However, it is widely considered that providing formal education or schooling is pretty much needed in the present day. Formal education which is obtained by attending school and Informal education that is done at home shall be completing each other. Whiterington stated that education is about growth (Whiterington, 1985). Furthermore, it is said that teachers and parents, both at home and school, shall understand this very nature of this growth and how to cooperate and complement each others 
(Whiterington, 1985). Therefore, many education-related problem shall be disappear. This also means should parents and school's teachers fully aware of their responsibilities, as well as of parts to take in educating children, the output of the process would be impressive and meaningful for children growth. Parents just could not afford to hand all responsibility to the teachers, while teachers and schooling staff are in need of support from parents to ensure fruitfulness of materials taught before.

Supposing that Whiterington point of view is true, schooling could not bear all the burden. It primarily provides question to answer, especially when it comes to intellectual and social character. Schooling remains major institution for education, particularly for development of upper psychological traits (Whiterington, 1985). This is due to different set of characters schooling has to offer compared to ones delivered through parental guidance at home. Albeit, those two should support each others.

\section{Children-Friendly Schooling}

Children-Friendly Schooling is a formal education alternative which consciously puts effort to ensure and to provide children's rights in every aspects neatly and responsibly (http://dp3akb.jabarprov.go.id). It creates safe and sound space of education. Also, it manages to overcome bullying issues that oftentimes becomes a matter to handle, because it enables education and schooling staffs to use special approach to develop the student compared to the ordinary school.
Children-Friendly Schooling is an ideal form of schooling with assurance towards four children's basic rights, as mentioned on Convention of Children Rights:

1) Survival Rights

Includes right to continuing life and preserving life through health insurance and proper treatment.

2) Protection Rights

Includes protection against bullying and discrimination, violence, and desolation.

3) Development Rights

Includes right to grow and thrive to desired state; covering education both formal and informal, as well as proper physical, psychological, moral, and social development.

\section{4) Participation Rights}

Includes rights to ask regarding their own curiosity.

Survival Rights are basic ones and guaranteed by the government. Article 28 A of National Constitution of 1945 regulates living and preserving life. It appears to be absolute right, one to be held with no exception. In this regard too, Children-Friendly Schooling is obliged to deliver this with no exception.

Children-Friendly Schooling shall provides protection against all kinds of violence; including physical, sexual, and emotional violence. Teachers, parents, trustee or caregiver, they all have to ensure proper treatment to get off of desolation and abandonment; whether in terms of food, clothing, shelter, even proper seating at school, as well as encouraging and bolstering environment; they all need to be taken care of. Student whose physical and psychological needs are fulfilled properly will start to value their friends, parents, teachers, and others. 
As the golden rule says, a student which treated tenderly will get used to treat others tenderly too.

Children-Friendly

Schooling ensures fair and square opportunities to thrive. All students are entitled to the same room of creativity, equal chance to express their feeling, and platform to participate regarding their age and maturity. All the teachers and teaching staffs provide fair treatment without gender-related biases; as well as any form of ethnicity, religion, racial, wealthiness, and all physical limitation. Enrichment by implementing local norms would be great addition and enforce diversity (http://dp3akb.jabarprov.go.id).

Children-Friendly Schooling enables equal student opportunity to participate. It shall encourage freedom to speak, ask, think, organize, and to embrace any religion and belief. Also, it teaches ethics on expressing opinion and thinking, albeit they will get used to speak and listen courteously.

It also creates supportive spaces to learn so all student feel content and pleased to express their potentials. Therefore, it shall be assisted by (1) robust schooling program encouraging environment and (3) supportive infrastructures.

Children-Friendly Schooling presupposes fit schooling program design which relates to every step of children development. They are not required to complete certain task or assignment yet encouraged to automatically explore their persona. One important factor to play is active participation towards various events and programs, but convenient to their best interest (http:/ /dp3akb.jabarprov.go.id).

Children-Friendly needs $\begin{array}{r}\text { Schooling } \\ \text { supportive }\end{array}$
$\begin{aligned} & \text { likewise } \\ & \text { environment } \\ & \text { (http://dp3akb.jabarprov.go.id). As }\end{aligned}$
for mentioned, physical environment in form of neat and clean rooms, access to clean and consumable water, protection against germs and bacteria, sufficient nutrition supply, etc. This kind of situation and facilities also need to be backed by corresponding family. Whiterington (tahun berapa) stated that guidance from competent teachers, supporting environment, and serious efforts simultaneously accelerate progress of a child development regarding their own heredity pattern. Furthermore, He stated that great leadership and direction displayed at school are required likewise. On this basis, suppose that they need to state clear objectives supported by well-arranged program and encouraging environment.

Infrastructure are necessary condition as well. Classroom, Teachers room, Teaching Staffs, and all essential spaces. Students are being involved in sitting arrangement that accommodate their creative works and creation. This involvement is significant towards students' creativity, confidence, and convenience.

One of common benchmark is fulfillment of its education standard. DP3AKB of West Java Province states, in the practice, there are 8 measurement standard for childrenfriendly schooling (http:/ /dp3akb.jabarprov.go.id):

1) Alumnus Criteria

Is used for appraisal guidance and graduate criteria regarding respective education level. 
2) Education Blueprint and Curriculum Standard

Includes a) study and learning load b) curriculum with various degree of education level c) academic calendar.

3) Teachers and Teaching Staffs

They have to possess certain academic qualification and set of competencies as learning agent, fit both physically and psychologically, capable of embody national education objectives.

\section{4) Process}

Learning process have to be interactive, inspiring, fun, challenging, and motivating, igniting their source of creativity and make enough space for their willing, creativity, and independent according to their respective best interest and talent, growth, and maturity.

5) Infrastructures

a) Should meet the minimum requirement for a school furnishing: school equipment, teaching tools and media, books and other supporting sources, and consumables

b) Should meet the minimum requirement for a classroom, head office, teachers and teaching staff room, administration room, library, laboratory, workshop, production chamber, canteen, room for general services, gymnasium, praying room, recreation room, and playing room.

6) Financing

Below are minimum requirement for investment details:

c) Including financing for infrastructures, human resources investment, and fixed capital.

d) Including personal spending; a periodical tuition fee so they could attend all the session and class regularly.
Below are minimum requirement for operational fee:

a) Salary and all fringe benefit for all the teachers and teaching staffs

b) Office supplies, amenities, and consumables

c) Indirect cost including electricity, water, communication, infrastructure maintenance, overtime, consumption, transportation, tax, insurance, etc

7) School Management

a) Management for each education level by government officials

b) In primary and secondary education: implementing school-based management which aims independence, cooperation, participation, transparency, and accountability.

In higher education: implementing higher education management which are regulated by constitution in order to ignite freedom and independence

8) Education Assessment

This is acknowledged as national standard for academic assessment including methods and procedures, as well as instrument for academic measurement

To date, regulation which is considered as the main reference in development of children-friendly schooling is Ministerial Decree No. 8 year 2014 of The State Ministry of Women Empowerment and Children Protection about Children-Friendly Schooling Policies. However, this decree have not covered all aspects thoroughly that we see the implementation might be derailed in some ways. Hence, measurement, standard to set, and teaching model are open for discussion. 
According to Ministerial Decree No. 8 year 2014 of The State Ministry of Women Empowerment and Children Protection about ChildrenFriendly Schooling Policies, the basic principles are:

1) Non-discriminative; it ensures equal opportunity for every children to benefit from education to the fullest without classification of physical disability, gender, ethnicity, race, religion, and any of their background.

2) It serves child' best interest; to become the center and main consideration in every decision and policies made by school organizer regarding their students

3) Living, survival, and personal development; to create supportive environment that protect their dignity and to ensure holistic and integrated growth.

4) Wide respect to all point of view; including freedom to speak and express their outlook in everything which related to their schooling life

5) Good governance that is making sure of transparency, accountability, participation, naked information, and law supremacy in every level of education

Those five principles are aligned with Four Points of Children Rights Convention above. Furthermore, these principles are need to be socialized especially for teachers, mentors, parents and trustee, so that they could guide student growth properly towards the desired adulthood

Now the main obstacle is curriculum. It is difficult to accommodate both standard of the ordinary curriculum for designated education level and particular standard and program a special schooling like this children-friendly schooling should have. One of effective countermeasure experts have been proposed before is bringing incurriculum and extra-curricular method. Considering that this schooling system is new and currently undergoing development, childrenfriendly schooling shall be open for further ideas and development, so that this could be fully implemented in the future.

\section{Conclusion}

According to discussion above, the author concludes that: Childrenfriendly schooling is a strong manifestation of fulfillment of the children rights to education. To do so, it chooses special approach with nondiscrimination, serving children's best interest, preserving one's life sustainability, respecting every ideas, as well as practicing good governance in order to achieve desired education standard with added focus of protecting they growth and development period. Although further studies and ideas are still needed, at very least the current standard might stand and ensure child rights to education.

\section{References}

Ignatius Dharta Ranu Wijaya, (no year), "Questioning the Prospects of the 12-Year Compulsory Education Program". Academia Edu.

Jeanne Ellis Ormrod, 2009, Educational Psychology, Helping Students Grow and Develop, Volume I, Jakarta: Erlangga Publisher.

Large online Indonesian dictionary, accessed November 10th 2019.

R.I. Sarumpaet, 1996, Secrets of Educating Children, Third 
Printing, Bandung: Indonesia Publishing House.

Whiterington (trans. M. Buchori), 1985, Educational Psychology, 5th printing, Jakarta: New Script.

Convention on the Rights of the Child. Law of the Republic of Indonesia

Number 23 of 2002 on Child

Protection.

Law Number 20 Year 2003 concerning the National Education System.

Regulation of the Minister of Women

Empowerment and Child

Protection of the Republic of

Indonesia Number 8 of 2014 concerning Child Friendly School Policy.

http://dp3akb.jabarprov.go.id/menge nal-dan-membembangan-schoolramah-anak/, accessed on November 10th, 2019.

http://jadipaham.com/45-butirpengamalan-pancasila-sila-ke-1sampai-sila-ke-5/. accessed on November 14th 2019.

https:/ / news.detik.com/berita/d4532984/kpai-angka-kekerasanpada-anak-januari-april-2019masih-tinggi 